\title{
The Steps Taken by The Prophet Muhammad In Building Da'wah And Islamic Civilization In Medina According to The Book of Ar-Rohiqul Makhtum
}

\author{
$1^{\text {st }}$ Mohammad Izdiyan Muttaqin ${ }^{1}, 2^{\text {nd }}$ Usep Abdul Matin $^{2}$ \\ \{moh.izdiyan@ui.ac.id ${ }^{1}$, usep.abdulmatin@uinjkt.ac.id ${ }^{2}$ \} \\ University of Indonesia ${ }^{1,}$ \\ UIN Syarif Hidayatullah Jakarta ${ }^{2}$
}

\begin{abstract}
This study aims to reveal the real steps taken by the Prophet Muhammad in Medina, which enable Muslims to develop a strong and influential civilization in the World. This is library research. The author used the book Ar-Rohiqul Makhtum by AlMubarakfuri as the main reference. The author reached the conclusion that the Prophet Muhammad took several strategic steps in his da'wah in Medina, including 1) Building a Mosque, 2) Brothering Muslims from the Muhajirin and Ansar, 3) Making a peace treaty with all of the Medina Citizens. The author agrees with Nabil As-Samaluti (2019) and Imam Amrusi Jailani (2016) that the concept of the State of Medina is a concept of peace for the entire citizens. This article also supports Komaruddin (2011), who stated that the Islamic State was not founded by coercion and violence.
\end{abstract}

Keywords: State of Medina, Ar-Rohiqul Makhtum, Al-Mubarakfuri

\section{Introduction}

The history of da'wah or Islamic Preaching has actually started since Adam AS was created. Prophet Adam must teach his descendants to believe and carry out the commands of Allah SWT. The prophetic and da'wah treatises were then continued by the Prophets after him, including the Prophets Idris, Noah, Ibrahim, Ismail, Jesus, to the last Prophet, Muhammad SAW. Every Prophet and Apostle has shown a good example in preaching, as well as in developing education and teaching for his Ummah. And the Da'wah of the Prophet Muhammad SAW is the most ideal example to be imitated because his time is closest to the civilization of modern society today.

The concept of how an ideal Islamic State would look like is a topic of endless debate. Scholars began to spend their energies discussing this issue a long time ago. The debate on this matter became more and more interesting after the end of the Ottoman Empire in 1924. Which provided an opportunity for Muslim countries to create the modern Muslim States that we're able to survive and adapt to the modern society. The 20th century became an important century for Muslims, because, in this century, the concept of the caliphate was adopted by Muslims for more than a thousand years (since the election of Abu Bakr in 632 AD. Until the collapse of the Ottoman Caliphate in 1924 AD), finally ended. The Ottoman Empire broke apart, and the concept of the Caliphate was no longer used by most Muslims since then, until now[1]. 
The end of the caliphate was the starting point of the emergence of new Islamic Countries after World War. This situation gave a new nuance to the development of the Islamic world. Some Muslim countries choose the concept of democracy which is considered in line with the principle of shura in the Qur'an. Then emerged Islamic Countries in the form of the Republic, such as Pakistan, Iraq, Indonesia, etc. Some others use a monarchical system, such as Saudi Arabia, Morocco, and also Gulf countries, such as Qatar, Kuwait, United Arab Emirates, and so on[2].

The end of the Caliphate system also raises a debate about whether we should re-establish the Islamic Caliphate. There were also movements that tried to rebuild the Islamic Caliphate, as known later as ISIS (Islamic State of Iraq and Syria). The concept of an Islamic State formed by ISIS caused controversy within the Muslims and the World Community. Most of them refused the concept, but there was also support that came from various countries, including some Indonesians who sympathized with ISIS[3] and supported ISIS until they finally left for Iraq and Syria to provide their support[4].

The emergence of various forms of government in the Islamic world is an attempt done by modern Muslims to maintain Islamic traditions while keeping the strength of the Institution by forming a Government that is strong and able to survive in modern times. There is some interesting research related to this theme. Among them is the article of Komaruddin (2011) which questions the need for an Islamic Preaching movement to form a state. Does an Islamic Movement require its people to form a State? Or does the State need to actively carry out Islamic Da'wah? Komaruddin argues that this radical attempt to establish an Islamic Caliphate in this modern era may be counter-productive and can cause losses and casualties for the Muslims themselves. He suggested a more peaceful approach to form an Islamic Da'wah movement, so it will not cause much harm among Muslims[5].

Related research that is also interesting for us to study is Sabdo's research from the University of Muhammadiyah Metro (2018) which tries to reveal how an ideal Islamic State should look like, based on the Qur'an and As-Sunnah. Which is often mentioned by the preachers, as "Baldatun Thoyyibatun wa Robbun Ghofur". These words were mentioned in Qur'an in Chapter Saba' verse 15. Based on his research, Sabdo revealed that the ideal Muslim country as built by the Prophet Muhammad SAW has several characteristics, namely: a country with Islamic brotherhood, a peaceful constitution, equality, perfect education, foreign diplomacy, a prosperous economy, security, and the obedience to the Islamic Religion[6].

Sabdo's research (2018) was continued by Abdul Haris (2018) which revealed the leadership characteristics of the Prophet Muhammad in building the State of Medina, including the spirit of brotherhood, equality, tolerance, deliberation, helping each other, and justice[7]. Meanwhile, Imam Amrusi Jailani (2016) from UIN Sunan Ampel, emphasized that the Medina charter made by the Prophet Muhammad was a clear basis for the formation of a constitutional state. A democratic country with a heterogeneous society[8].

Meanwhile, Nabil As-Samaluti (2019) from Al-Azhar University in Cairo argues that the Medina State founded by the Prophet Muhammad is an early form of a Constitutional State. A country that respects diversity and guarantees the rights of minorities. According to Nabil, the Islamic State of Medina was built on the basis of peace for all, by guaranteeing human rights for every citizen. The Medina State system, according to As-Samaluti, only existed during the time of the Prophet Muhammad and Rightly Guided Caliphs. And we don't find it again after that era [9].

The studies above give us an idea of what an Islamic State should be like. However, there is an interesting question that arises from the studies above, namely, what concrete steps did the Prophet Muhammad take in building Medina? Not only its values, as revealed by Sabdo (2018), 
Abdul Haris (2018), and Amrusi (2016) Furthermore, is it possible for the State of Medina to be re-embodied in Modern Society? Or is it impossible at all, or almost impossible, as Nabil AsSamaluti (2019) argues? So this study tries to answer some of these questions, based on historical records in the books of Rohiqul Makhtum and Siroh Ibn Hisham. The author in this paper wants to reveal practical and concrete steps that were actually carried out by the Prophet Muhammad SAW in pioneering the establishment of the Islamic State of Medina which is considered a form of the Ideal State for the Muslim Community.

\section{Methodology}

This research is library research[10] based on the information found in books related to the topic. The main reference used is the Biography of The Prophet Muhammad which is quite popular among Muslims, namely Al-Mubarakfuri's book Rohiqul Makhtum. In addition it, the author also refers to Ibn Hisham's Siroh Nabawiyah, which is one of the oldest history books about the Prophet Muhammad's life, and is considered one of the main references to the history of the Prophet Muhammad. These references are read and the information contained in them is combined to form conclusions that are displayed at the end of the article.

\section{Result and Discussion}

\subsection{About The Book Of Rohiqul Makhtum And Al-Mubarakfuri}

The book of Rohiqul Makhtum is considered one of the best Siroh Nabawiyah books produced in modern times. This book summarizes the life of the Prophet Muhammad in quite a detail in one book. This book consists of approximately 470 pages. The number of pages is quite concise with fairly complete content. This book was the winner in the competition for writing the biography of the Prophet Muhammad SAW organized by the Islamic World Association which was held in Pakistan in 1396 H[11]. This book took first place out of a total of 170 authors who took part in the competition.

The book of Rohiqul Makhtum is gaining tremendous popularity in the Muslim World, this book is admired and read by many people. Because this book explains the life story of the Prophet Muhammad in a language that is easy to understand, not complicated and not difficult. As if this book explains events in the past with the language of today, so that the reader does not experience difficulties when reading it. The author of Rohiqul Makhtum also used a contemporary historical writing style that focuses on narrative and storyline and does not elaborate much on the origin of the news or the chain of information it contains. This makes it easier for readers to understand the outline of the life story of the Prophet Muhammad. What makes the book interesting, too, is that this book was written by a non-Arab person, AlMubarakfuri is a Muslim scholar from India. Of course, Arabic is not his original language, therefore the language he used can be more easily understood by non-Arab readers.

Sheikh Mubarakfuri (4 June 1943-1 December 2006) was one of the scholars of hadith in India. He has participated in various scientific activities in various regions in India, the United States, and Saudi Arabia. He has also worked as a researcher at the Islamic University of Madinah for 10 years since 1988. He has written various books in both Urdu and Arabic. And his most famous work is Ar-Rohiqul Makhtum. 


\subsection{The Steps Taken by The Prophet Muhammad In Building Da'wah And Islamic Civilization In Medina}

Islamic da'wah began to find light in the eleventh year of prophethood. At that time, during the pilgrimage season, The Prophet PBUH invited people who came from various regions to believe in Allah SWT. The Prophet Muhammad met some people who came from Medina. He then invited them to believe in Islamic Religion. They finally accepted the message of the Prophet Muhammad and confirmed his teachings. In the twelfth year of prophethood, the group from Medina came back to Mecca, and this time they were in greater number. They then made an agreement with the Prophet Muhammad, who would later be referred to as the First Aqaba Oaths of Allegiance[12]. Within that declaration of allegiance, they swore to be loyal to the teachings of Islam, and to leave the prohibitions that are prohibited by Islam. They also asked the Messenger of Allah to send his companion to teach Islam in Medina. So Mus'ab bin Umair was sent to teach the Qur'an to the people of Medina. Mus'ab bin Umair is considered the first Islamic ambassador to be sent to a new area where the majority of the population is not yet Muslim. Mus'ab bin Umair then tried his best to preach and teach about Islam to the people of Medina. Mus'ab was finally able to carry out his da'wah duties very well. It was Mus'ab bin Umair's da'wah that later became the initial foundation for the success of da'wah in Medina. Many of the residents of Medina converted to Islam that year, including the respected people of Medina[13].

The success of Mus'ab bin Umair's in Medina, then continued with the second Aqaba Oaths of Allegiance, which took place in the thirteenth year after prophethood. Seventy-three people came to Mecca to pledge allegiance to the Prophet Muhammad. In that moment, the people of Medina swore to maintain the allegiance to the Prophet Muhammad, and were ready to fight for his da'wah, just like defending and protecting their own children. These oaths then became the solid foundation for building a strong relationship between the Prophet and the People of Medina. And Islamic da'wah again spread in Medina with a very rapid spread[14].

If we analyze, actually the Prophet Muhammad and the city of Medina have a fairly strong emotional relationship. Because the grave of the Prophet's father is in Medina, while the grave of his mother is near Medina. On the other hand, the spread of Islam in Medina actually has a fairly strong political dimension. Muslims in Medina at that time really missed the arrival of the Prophet Muhammad because they needed a leader who could help them to face economic and political competition with the Jews who were the minority population in Medina[15]. The Muslims of Medina have heard about the emergence of a New Prophet from the Jews, as predicted by Prophet Isa. The Arabs of Medina knew it from the Jews who live in Medina. The Jews believed that the new Prophet would later emerge from the Jews, and would help them to defeat the Arabs. But in reality, the new Prophet emerged from the Arabs. Because of this, the Arabs in Medina are so happy. They welcomed the Prophet Muhammad. Because they have heard the news about the emergence of the Prophet Muhammad SAW since long time ago, from the Jews of Medina.

The next step taken by the Prophet Muhammad was the migration to Medina, which became an important historical step in the process of establishing the first Islamic State in history[8]. This migration movement was then carried out by his Companions. They left their steady life in Mecca to fight for the development of Islamic Religion and Islamic Civilization in Medina. In a relatively short time, Islamic Religion began to develop in Medina. With such a large number 
of Muslims, The Prophet Muhammad was able to do important things for the establishment of Islamic Civilization in Medina.

The process of da'wah in Medina is considered an important step in the history of Islamic da'wah, a new phase after the da'wah in Mecca. Al-Mubarokfuri himself defined this with an interesting title, namely: "Bina' Mujtama' Jadid"[16]. Or Building a New Society. Because in Medina Rasulullah SAW is considered to have taken strategic steps to build a new political force. An Islamic State that emerged in the middle of the Arabian Peninsula, which would later transform into one of the most influential political forces both at the regional and international levels.

The selection of the location of the mosque and the house of the Prophet SAW is also interesting, when the Prophet Muhammad arrived in Medina, he was offered by Utban bin Malik, and Abbas bin Ubadah bin Nadhlah, and several people from Banu Salim bin Auf to live in their place, the Prophet then refused and said, "Let this camel free to walk, in fact, it has received orders". This shows resignation and submission to God in decision making. A decision that, of course, minimized disputes between the people of Medina. Then the camel then walked and approached the settlement of several tribes, every time the camel stopped at one of the tribes, the people of the tribes would ask the Prophet Muhammad to come down and live with them. But the Prophet Muhammad still tells them to let the camel walk. Until finally the Prophet's Camel stopped and sat in the settlement of Bani Malik bin An-Najjar. This location will later become the Prophet's Mosque and the house of the Prophet Muhammad. The location at that time was a Mirbad, which is a place for drying dates. The land belonged to two orphans in Medina who later sold it to the Prophet Muhammad[17].

Al-Mubarokfuri described that the Prophet Muhammad began the construction of this New State by saying, "here is the house". He determined the position of his house next to the house of his noble companion, Abu Ayyub Al-Anshori. In the house of Abu Ayub the Messenger of Allah then lived while he did not have a home. Ibn Hisham in his Siroh describes that the Prophet Muhammad at that time lived in the house of Abu Ayyub as a guest. And Abu Ayyub's house did not seem to have many beds, so the Messenger of Allah (SAW) refused to sleep on the bed, while Abu Ayyub slept on the floor, he chose to sleep on the floor, and asked Abu Ayyub to stay on the bed[17]. A decision that shows the extraordinary nobility of morality. Unlike Ibn Hisham's Sirah Nabawiyah Book which narrates every incident with a detailed explanation using the sanad and its source, Al-Mubarakfuri described the process of the establishment of the State of Medina in a more concise and clear manner. Without going into too much detail, he immediately divided the steps for building a New Society in Medina into three main steps:

\subsubsection{Building a Mosque}

Not so long after the Prophet Muhammad arrived in Medina, he took the initiative to build a house and a mosque. His house and mosque were built on the land where his camel had stopped, in a Mirbad (date drying place) which belonged to Sahl and Suhail bin Amru, two orphans raised by the Bani Najjar. There are scholars who think that the Prophet Muhammad bought the land, and some others think that the companions bought the land. The mosque was built in mutual cooperation between the citizens of Medina from Muhajirin and Ansar. This activity certainly made their sense of unity even more powerful. Al-Mubarakfuri also featured one of the famous poems sung by the Prophet Muhammad SAW when building the mosque: Allah has no life except the hereafter, so forgive the Ansar and the Muhajirin[16]. 
The location of the mosque was previously neglected land. There are several graves of the polytheists. Prophet Muhammad then ordered to move it. There are also tree trunks and plants that are not really needed. So the Prophet and his Companions cleared the land and started building the mosque. The mosque was built with simple raw materials. Of bricks and cement arranged. The Qibla of the mosque still faces Baitul Maqdis. The poles are also still using date palm trunks. The floor is still sand and gravel. The mosque is given three doors. The length of the mosque is 100 dzira'. While the other side is the same length or less. The foundation that is built is almost 3 dzira' thick[16].

This mosque was later called the Prophet's Mosque. The mosque later became the center of the Prophet's da'wah activities in Medina. In the mosque, the Prophet Muhammad gave messages of da'wah and Islamic teaching to his Companions. There the Prophet also received guests who came from various regions. This includes non-Muslims, whether they are Judaism, Christianity, or Paganism. Al-Mubarakfuri argues that this mosque is also an important element that unites the Arab tribes in Medina. This mosque unites them in one Islamic brotherhood that makes them forget about the long war that has occurred between the Arab tribes[16].

The mosque is also a place to do the deliberation between the Prophet Muhammad and his companions, to decide important decisions related to da'wah and the affairs of the Muslim Ummah in general. So the mosque is also the center of government of the Islamic State which was built by the Prophet Muhammad. Not only that, but the Prophet's Mosque is also a military command center, where the Prophet Muhammad formed and managed his troops, before being sent to areas that would later become the battlefield of the Muslims, both against the Quraysh infidels, and against the Arab tribes. throughout the Arabian Peninsula. After the death of the Prophet Muhammad, the Prophet's Mosque was also used as a place to hold bai'at or the oath of allegiance for the rightly guided caliphate or khulafaurrasyidin, the successors of the Prophet Muhammad, namely Abu Bakr, Umar, Uthman, and Ali, radhiyallahu 'anhum[18].

Al-Mubarokfuri also argues that the mosque in the time of the Prophet was a combination of the Government Building and the Parliament Building, because the building carried out the executive and legislative functions of the Islamic Government in Medina. Not only that, the Prophet Muhammad's Mosque is also a home for some believers who do not have a place to live, who recently emigrated from Mecca and from other places. Because some of them do not have families, provisions, or houses, the mosque becomes a place for them to live and worship[16].

\subsubsection{Fraternizing the Muhajirin and Ansar}

This step became very important because the Emigrants or Muhajirin came to Medina as newcomers. Some of them are poor people who leave their homes and property to seek the pleasure of Allah. So when they arrived in Medina, most of the Emigrants, including the Prophet Muhammad, did not yet have a house in Medina. So they need new brothers so they can survive for a while, brothers who will provide the basic needs to live. So that they have a place to live and food that can be accessed from their Muslim brothers who have lived long before them in Medina. With this step, the unity of the Muslim Ummah is formed. Economic and social stability also became better, so that subsequently became the main capital to develop da'wah in their new land, namely Medina[16].

Al-Mubarokfuri explained this incident by quoting the explanation of Ibn Al-Qoyyim who narrated that the Messenger of Allah (PBUH) brought the Muhajirin and Ansar people 
together at Anas bin Malik's house. In that event, 90 friends gathered. Half from the Ansar and the other half from the Al-Muhajirin. The Messenger of Allah then brought them together equally. They even inherited each other's inheritance, until then a verse came down that forbade it (Qur'an 8: 75). So after that, the inheritance process between them was stopped. Al-Mubarokfuri also quoted Al-Ghozali's opinion, that this brotherhood between Muhajirin and Ansar serves to eliminate fanaticism of ignorance so that there is no sense of loyalty and love except for Islam. In order to lose the differences between lineage and tribe. So no one is considered noble or despised by someone except because of his character and obedience to God's order. This theory is not only a theory for the Prophet Muhammad, but he made it happen in real life. Manifested by friends by risking their property and lives. Not just the words that come out of the mouth[16].

Al-Bukhari narrated that when the Emigrants had entered Medina, the Messenger of Allah (PBUH) brought brother between Abdurrahman and Sa'ad bin ar-Robi', then Sa'ad said to Abdurrahman, verily I am the richest person among the Ansar, so I divide my wealth. into two parts. I also have two wives, so take the one you like the most, say his name, and I will divorce her. If the period of iddah has been completed, then marry her. Abdurrahman replied, "May Allah bless you, your family, and your wealth, and where is your market?". So they showed them the location of the Bani Qoinuqo' market, and when Abdurrahman returned he had made a profit, and not long after that, Abdurrahman was married and gave gold ore as a dowry to his wife[17].

This illustrates how serious the Ansar were in dividing their wealth and supporting the Muhajirin. They do not hesitate to give their wealth, even their wives to provide mental and financial support to their Muhajirin brothers and sisters. But on the other hand, the Muhajirin were also very careful not to just keep silent and ask their Ansar brothers. They also have skills and use their skills to make a living, so they can live independently.

\subsubsection{Islamic Alliance Agreement}

In addition to fraternizing the Muhajirin and Ansar, the Messenger of Allah (PBUH) also makes an agreement to eliminate the barriers of ignorance and disputes between tribes. Rasulullah SAW also did not allow bad habits of ignorance to linger in Muslim society. This is done by entering into an agreement between the Muslims[8], this agreement according to Al-Mubarakfuri in Rohiqul Makhtum is as follows:

This is the writing of Muhammad the Prophet SAW between the believers and Muslims from the Quraysh, Yathrib, and those who went with them, followed them and fought with them:

1. That they are one Ummah that is different from the others.

2. The Muhajirin of Quraish are in their group and united among them, and they will sacrifice what they have for the weak and their captives for the realization of truth and justice among the believers.

3. The Ansar are in their group and united among them, and they will sacrifice what they have for the weak and their captives for the realization of truth and justice among the believers.

4. Verily the believers will not allow anything for nothing but will be donated for the sake of truth to redeem and help the weak.

5. And indeed the pious believers will fight against those who oppose them, or who want evil, injustice, sin, enmity, or damage among the believers. 
6. And that their hands are united over it (all one word) even though it is against their own child.

7. And the believer should not kill the believer for the sake of the disbeliever

8 . And the believers do not win over the disbelievers

9. And that Allah's protection (Dhimmatullah) is one, they protect those under them.

10. And that those who come with us from the Jews will be helped and modeled, not to be threatened, and the Muslims will not wrongly help to harm them.

11. And the peace treaty of the Believers is one. Do not make a peace treaty with one believer without another believer in a war in the way of Allah except with truth and justice between them.

12. And that some of the believers prioritize others in making sacrifices in the way of Allah SWT.

13. And verily if a believer kills another believer clearly, then he will be sentenced to death unless the guardian who is killed is willing to accept a diyah (fine).

14. And verily the believers are entirely against it, and it is not permissible for them except to carry out the justice.

15. And verily it is not permissible for a believer to help an adulterer, nor to protect him, and verily whoever helps him or protects him, then indeed is the curse of Allah and His wrath on the Day of Resurrection. And he will not be accepted for his witness.

16. And verily, if you differ in a matter, then the place of return for everything is to Allah (SAW) and to Muhammad (PBUH).

Such is the text of the agreement of the Medinan Believers in the book of Rohiqul Makhtum. The text of the Medina charter is considered by some to be the initial form of the Constitution in a State. This law became the basis for the establishment of the Islamic State at the time of the Prophet Muhammad[8]. Al-Mubarakfuri argued that the Medina Law was an attempt by the Prophet Muhammad to lay the foundations of a New Society. And this also has a great influence on the formation of the morals of the Companions of the Prophet Muhammad SAW[16].

Al-Mubarakfuri also argues that in fact all these laws are also strengthened by the education and direction from the Prophet Muhammad (PBUH) who always pays attention to the nobility of character and compassion for others. The Prophet also emphasized the need to look after others, to help each other, and to maintain security in society. The Prophet also emphasized the importance of unity within the Muslim Ummah, so that there is no division between one and another. The Prophet also emphasized the importance of staying away from bad things that will cause division, such as oppressing each other, envying each other, backbiting, and so on.[16]

The important thing that we also need to remember is that when the Muslims had strong political and military power in Medina, the Prophet Muhammad continued to carry out the process of da'wah in stages. The first thing he did was to send letters to the Kings around him[19]. He did not immediately declare war on them, but Rasulullah SAW invited them to convert to Islam peacefully. This step is also an important example in the concept of da'wah in Islam, that a leader in an Islamic State should carry out a mission of da'wah in his politics, and try to convey and invite the surrounding authorities to know the message of Islam, and it begins in peaceful ways. 


\section{Conclusion}

With consistency in Da'wah and education carried out by the Prophet Muhammad and the first generation of Muslims, finally, Muslims are able to maintain Islamic values, and spread them to various regions in the world. The success of Da'wah and Islamic Education in the first generation is what later gave birth to figures who were called the best generation by the Prophet Muhammad. Al-Mubarakfuri in Rohiqul Makhtum argues that the establishment of da'wah and education of the Prophet SAW in Medina started with creating a "New Society" or what is considered a "New State" by carrying out three important initial steps: Building a mosque, brothering Muslims in Medina, and making an agreement. with the people of Medina to help and support each other in realizing justice and peace. This paper supports previous studies that oppose efforts to establish an Islamic State by means of violence and coercion, because the Prophet Muhammad did not establish a state by force and coercion, but with the support and agreement from the entire population in Medina.

\section{References}

[1] F. Rahman, "Sejarah Perkembangan Islam Di Turki," Tasamuh J. Stud. Islam, Vol. 10, No. 2, Pp. 289-308, 2018, Doi: 10.47945/Tasamuh.V10i2.74.

[2] "Qatar: A Modern History," Choice Rev. Online, 2012, Doi: 10.5860/Choice.50-1645.

[3] F. B. L. Tobing And E. Indradjaja, "Islamic State In Iraq And Syria (Isis) And Its Impact In Indonesia,” Glob. J. Polit. Int., 2019, Doi: 10.7454/Global.V21i1.365.

[4] N. K. Rijal, "Eksistensi Dan Perkembangan Isis: Dari Irak Hingga Indonesia," J. Ilm. Hub. Int., 2017, Doi: 10.26593/Jihi.V13i1.2670.45-60.

[5] K. Komaruddin, "Dakwah Islam Dan Keharusan Pembentukan Negara," Wardah, Vol. 12, No. 1, Pp. 47-53, 2011, Doi: 10.19109/Wardah.V12i1.216.

[6] Sabdo, "Konsep 'Baldatun Thoyibatun Wa Robbun Ghofur' Sebagai Tujuan Akhir Proses Tranformasi Sosial Islam," 2018.

[7] A. Haris, "Peranan Nabi Muhammad Sebagai Pembangun Masyarakat Madani Dan Peletak Dasar Peradaban Islam," Al-Munawwarah J. Pendidik. Islam, Vol. 10, Pp. 12-30, 2018.

[8] I. A. Jailani, "Piagam Madinah: Landasan Filosofis Konstitusi Negara Demokratis," Al-Daulah J. Huk. Dan Perundangan Islam, Vol. 6, No. 2, Pp. 269-295, 2016, [Online]. Available:

Http://Jurnalfsh.Uinsby.Ac.Id/Index.Php/Aldaulah/Article/View/114\%0ahttp://Jurnalfsh.Uinsby.Ac.I d/Index.Php/Aldaulah/Article/Download/114/Pdf_10.

[9] N. As-Samaluti, "Fan Bina Ad-Daulah Baina Sahih Al-Islam Wa Baina Tathorruf Al-Jama'at AlIrhabiyah,” J. Qitho Dirasat Al-Insaniyah, Vol. 24, No. 1, 2019.

[10] F. Burchsted And E. Bell, "Library Research Guide For The History Of Science: Introduction," Harvard Libr., 2020.

[11] M. Y. Anis And F. R. Ash-Shidiqiyyah, "Penerjemahan Kalimat Imperatif Dan Kesalahannya Dalam Kitab Ar Rahīq Al Makhtūm Karya Syaikh Shafiyyurrahman Al Mubarakfuri," Lلسانـ J. Ilmu Bhs. Arab Dan Pembelajarannya, Vol. 10, No. 2, 2021, Doi: 10.22373/Ls.V10i2.8833.

[12] A. E. A. Sonbol, Women Of Jordan: Islam, Labor, \& The Law. 2003.

[13] U. S. Ali, "Peradaban Islam Madinah (Refleksi Terhadap Primordialisme Suku Auz Dan

Khazraj)," Kalimah, Vol. 15, No. 2, 2017, Doi: 10.21111/Klm.V15i2.1495.

[14] Abdussalam Muhammad Harun, Tahdzib Sirah Ibni Hisyam. Dar Al-Kutub Al-Ilmiyah., 2018.

[15] P. L. Rose, "Muhammad, The Jews And The Constitution Of Medina: Retrieving The

Historical Kernel," Islam - Zeitschrift Fur Geschichte Und Kultur Des Islamischen Orients, Vol. 86, No. 1. 2011, Doi: 10.1515/Islam.2011.012.

[16] S. Al-Mubarakfuri, Ar-Rahiqul Makhtum. Bahtsun Fi As-Sirah An-Nabawiyah Ala Shohibiha 
Afdholu As-Sholatu Wa As-Salam. Daru Ihya' Turats, 1976.

[17] I. Hisyam, As-Sirah An-Nabawiyah Li Ibni Hisyam Al-Mutawaffa Sanah 213 Aw 218 H.

Beirut: Darul Kitab Al-Arabi, Beirut, 1990.

[18] Duriana, "Pemikiran Politik Turki Usmani Hingga Masa Modern," Dialektika, 2018.

[19] A. A. Nurul Insani, "Dakwah Politik Nabi Muhammad Saw Melalui Surat Kepada Raja Heraklius, Kisra Abrawaiz, Muqauqis, Dan Najasyi," Islam. Commun. J., Vol. 4, No. 1, 2019, Doi: 10.21580/Icj.2019.4.1.3595. 